\title{
Mutations in the glycerol kinase gene restore the ability of a ptsGHI mutant of Bacillus subtilis to grow on glycerol
}

\author{
Christina Wehtje, Lena Beijer, Rune-Pär Nilsson and Blanka Rutberg
}

Author for correspondence: Blanka Rutberg. Tel: +4646 108629. Fax: +46 46157839 .

Department of

Microbiology, Lund

University, Solvegatan 21,

S-223 62 Lund, Sweden

\begin{abstract}
Although glycerol is not taken up via the phosphotransferase system (PTS) in Bacillus subtilis, some mutations that affect the general components of the PTS impair the ability of cells to grow on glycerol. Five revertants of a pts deletion mutant that grow on glycerol were analysed. They were shown to carry mutations in the glycerol kinase gene. These are missense mutations located in parts of the glpK gene that could encode regions important for the activity of glycerol kinase. The results strongly suggest that the main effect of the PTS on glycerol utilization in B. subtilis is mediated via glycerol kinase.
\end{abstract}

Keywords: Bacillus subtilis, glycerol catabolism, PTS components, glycerol kinase

\section{INTRODUCTION}

Glycerol catabolism in Bacillus subtilis involves a glycerol kinase (encoded by $g l p K$ ) which phosphorylates glycerol to glycerol 3-phosphate (G3P) and a G3P dehydrogenase (encoded by $g l p D$ ) which oxidizes G3P to dihydroxyacetone phosphate, an intermediate in glycolysis. $g l p F$ encodes a glycerol uptake facilitator and $g l p P$ encodes a regulatory protein. $g l p P, g l p F, g l p K$ and $g l p D$ are located at $75^{\circ}$ on the $B$. subtilis chromosomal map and they constitute three operons: $g l p P, g l p F K$ and $g l p D$ (Holmberg et al., 1990; Beijer et al., 1993). B. subtilis can also grow, although poorly, on G3P as sole carbon and energy source. This requires, in addition to the $g l p P$ and $g l p D$ gene products, a G3P permease which is encoded by the $g l p T$ gene. $g l p T$ is located at $15^{\circ}$ on the chromosomal map and is part of an operon that also contains the $g l p Q$ gene which encodes a glycerophosphoryl diester phosphodiesterase (Lindgren, 1978; Nilsson et al., 1994). The main control of the glp regulon of B. subtilis appears to be by termination/antitermination of transcription (Holmberg \& Rutberg, 1991, 1992). In the presence of G3P, the GlpP protein is thought to act as an antiterminator.

Glycerol enters B. subtilis via the glycerol uptake facilitator (Beijer et al., 1993), while glucose is taken up via the phosphotransferase system (PTS). Mutations that affect the general components of the PTS, Enzyme I (EI)

Abbreviations: Ap, ampicillin; Cm, chloramphenicol; El, Enzyme I; Ell, Enzyme II; Em, erythromycin; G3P, glycerol 3-phosphate; PTS, phosphotransferase system; Tc, tetracycline.

The GenBank accession number for the sequence reported in this paper is M34393. encoded by $p t s I$ and HPr encoded by $p t s H$, render the cells unable to transport glucose and other PTS sugars. Interestingly, some of them also impair the ability of cells to grow on glycerol (Gay et al., 1973; J. Deutscher, unpublished data). Mutations that affect the glucosespecific component Enzyme II ${ }^{\text {Gle }}\left(\mathrm{EII}^{\mathrm{Glc}}\right)$, encoded by $p t s G$, do not interfere with glycerol utilization (GonzyTréboul et al., 1991).

A ptsGHI deletion mutant (deficient in EII ${ }^{\text {gle }}, \mathrm{HPr}$ and $\mathrm{EI})$, which does not grow on glycerol, can grow on G3P. Furthermore, external G3P, but not glycerol, induces G3P dehydrogenase in this mutant (Beijer \& Rutberg, 1992). These findings demonstrate that expression of the $g l p D$ and $g l p P$ genes does not require the products of the $p t s G, H$ and $I$ genes and lead to the conclusion that the PTS is not concerned with the overall regulation of the $g l p$ genes. Revertants of the above pts mutant which grow on glycerol but not on glucose have been isolated. The corresponding mutations map at $75^{\circ}$ on the $B$. subtilis chromosome, i.e. they are closely linked to or located in the $g l p P F K D$ region (Beijer \& Rutberg, 1992). In this study we have characterized five such revertants. They all carry missense mutations located in parts of the $g l p K$ gene that could encode regions important for the activity of glycerol kinase. Our results strongly suggest that in $B$. subtilis, the main effect of the PTS on glycerol utilization is mediated via glycerol kinase.

\section{METHODS}

Bacterial strains. The bacterial strains and plasmids used in this work are listed in Table 1. LUG9001 was a derivative of wildtype strain BR95, carrying an $\mathrm{Em}^{\mathbf{R}}$ gene inserted between the pts $G 3^{\prime}$ end and the $p t s I 5^{\prime}$ end. The insertion was derived from 
Table 1. Bacterial strains and plasmids

\begin{tabular}{|c|c|c|}
\hline Strain/plasmid & Genotype/phenotype & Reference \\
\hline \multicolumn{3}{|l|}{ B. subtilis } \\
\hline BR95 & $\operatorname{trp} C 2$ phe $A 1$ ilvC1 & Our collection \\
\hline LUG0401 & $\begin{array}{c}\operatorname{trp} C 2 \text { pbe } A 1 \text { ilvC1 } \\
\triangle g l p P F K D \text { ble }\end{array}$ & $\begin{array}{l}\text { Holmberg et al. } \\
(1990)\end{array}$ \\
\hline LUG9001 & $\begin{array}{l}\operatorname{trp} C 2 \text { pbe } A 1 \text { ilvC1 } \\
\Delta p t s G H I \mathrm{Em}^{\mathrm{R}}\end{array}$ & $\begin{array}{l}\text { Beijer \& Rutberg } \\
\text { (1992) }\end{array}$ \\
\hline LUR9401 & $\begin{array}{l}\operatorname{trpC} 2 \text { pbe } A 1 \text { ilvC1 } \\
\Delta p t s G H I g l p K 1 \mathrm{Em}^{\mathbf{R}}\end{array}$ & This work \\
\hline LUR9402 & $\begin{array}{l}\operatorname{trp} C 2 \text { phe } A 1 \text { ilvC1 } \\
\Delta p t s G H I g l p K 2 \mathrm{Em}^{\mathbf{R}}\end{array}$ & This work \\
\hline LUR9403 & $\begin{array}{l}\operatorname{trpC2} p h e A 1 \text { ilvC1 } \\
\Delta p t s G H I g l p K 3 \mathrm{Em}^{\mathrm{R}}\end{array}$ & This work \\
\hline LUR9404 & $\begin{array}{l}\operatorname{trp} C 2 \text { pbe } A 1 \text { ilvC1 } \\
\Delta p t s G H I \text { glpK4 } \mathrm{Em}^{\mathrm{R}}\end{array}$ & This work \\
\hline LUR9405 & $\begin{array}{l}\operatorname{trpC2} \text { phe } A 1 \text { ilvC1 } \\
\Delta p t s G H I \text { glpK5 } \mathrm{Em}^{\mathrm{R}}\end{array}$ & This work \\
\hline \multicolumn{3}{|l|}{ E. coli } \\
\hline MM294 & pro thi end $A b s r_{\mathbf{k}} b s r_{\mathrm{m}+}$ & $\begin{array}{l}\text { Amann et al. } \\
(1983)\end{array}$ \\
\hline \multicolumn{3}{|l|}{ Plasmid } \\
\hline pHV32 & $\mathrm{Ap}^{\mathrm{R}} \mathrm{Cm}^{\mathrm{R}} \mathrm{Tc}^{\mathrm{R}}$ & $\begin{array}{l}\text { Niaudet et al. } \\
(1982)\end{array}$ \\
\hline pHP13 & $\mathrm{Cm}^{\mathbf{R}} \mathrm{Em}^{\mathbf{R}}$ & Haima et al. (1987) \\
\hline pLUM308 & $\begin{array}{l}\mathrm{Cm}^{\mathrm{R}} \mathrm{Em}^{\mathrm{R}} g l p P 142 \\
g l p F K g l p D^{\prime}\end{array}$ & This work \\
\hline pLUM305 & $\mathrm{Em}^{\mathbf{R}} g l p F^{\prime} g l p K g l p D^{\prime}$ & Our collection \\
\hline pLUM630 & $A p^{R} g l p K^{\prime}-Z Z$ & This work \\
\hline
\end{tabular}

QB6020 (a kind gift from Dr André Klier, Institut Pasteur, Paris). The insertion of QB6020 is in turn derived from GM329 (Eisermann et al., 1988). For mapping purposes, Beijer \& Rutberg (1992) integrated a plasmid containing a cat gene immediately downstream of $g l p D$ in LUG9001. From this derivative of LUG9001, they isolated independent revertants that can grow on glycerol as sole carbon and energy source. Before we continued the analysis of the revertants, their mutations were transferred to LUG9001 to eliminate the integrated plasmid. LUG9001 was transformed with chromosomal DNA from the revertants and transformants were selected on minimal glycerol plates. The transformants were checked for $\mathrm{Cm}$ sensitivity (i.e. the plasmid had not been transferred) and Em resistance (marker of LUG9001). The revertant strains were named LUR9401-9405.

Media. Bacteria were kept on Tryptose Blood Agar Base (TBAB) plates. The minimal salts solution was that of Anagnostopoulos \& Spizizen (1961) with the addition of a carbon and energy source; glucose $(30 \mathrm{mM})$, casamino acids $(0.5 \%)$, glycerol $(20 \mathrm{mM})$ or $\mathrm{DL}-\alpha-\mathrm{G} 3 \mathrm{P}(40 \mathrm{mM})$. Required amino acids were added at $40 \mathrm{mg} \mathrm{l}^{-1}$. Antibiotics were used at the following concentrations $\left(\mathrm{mg} \mathrm{l}^{-1}\right): \mathrm{Em}, 3 ; \mathrm{Cm}, 5 ; \mathrm{Ap}, 50$.

Transformation. Competent $B$. subtilis cells were prepared as described by Arwert \& Venema (1973). Eschericbia coli cells were made competent by the $\mathrm{CaCl}_{2}$ method described by Mandel \& Higa (1970).

DNA techniques. Chromosomal DNA was prepared as described by Marmur (1961). Plasmid DNA from E. coli was prepared using Qiagen (Diagen; maxi preparations) and plasmid
DNA from B. subtilis was prepared using Magic Maxipreps (Promega). DNA amplification was carried out by PCR with a GeneAmp kit (Perkin-Elmer Cetus). The nucleotide sequence was determined by the dideoxy chain-termination method of Sanger et al. (1977), using Sequenase version 2.0 (USB) and $\left[\alpha^{35}\right.$ S ]dATP. Both strands were sequenced using synthesized primers. The primers were located at 250 -bp intervals, giving overlaps in both directions. Restriction endonucleases and T4 DNA ligase were purchased from Boehringer Mannheim and used as recommended by the manufacturer.

Preparation of cell extracts and enzyme assays. Cell-free extracts were prepared as described by Lindgren \& Rutberg (1974). Cells were grown at $37^{\circ} \mathrm{C}$ in minimal salts solution with $0.5 \%$ casamino acids until $\mathrm{OD}_{600} 0.5$. The culture was then divided into three parts. Glycerol was added to one part and G3P to a second part. No addition was made to the third part. After $2 \mathrm{~h}$ incubation, cells were harvested and lysed. Glycerol kinase activity was measured as described by Freedberg \& Lin (1973), but with the buffer at $\mathrm{pH} 9 \cdot 0$ instead of 9.5. G3P dehydrogenase activity was measured as described by Lin $e t a l$. (1962). The amount of protein was determined by the Pierce BCA Protein Assay.

Generation of antibodies against glycerol kinase. The plasmid pTrcZZ (E. Holmgren, unpublished results) was used for constucting a GlpK-ZZ translational fusion. pTrcZZ is a derivative of $\mathrm{p}$ Trc99A (Pharmacia) with an insertion of a reading frame encoding a two-domain analogue of the IgG-binding staphylococcal protein $\mathrm{A}$, designated $\mathrm{ZZ}$. The $\mathrm{ZZ}$ cassette is preceded by a promoter (inducible by IPTG) and a cloning cassette. A $1.4 \mathrm{~kb}$ EcoRI-BamHI fragment covering most of $g l p K$ (starting $63 \mathrm{bp}$ upstream of the start codon and ending $133 \mathrm{bp}$ upstream of the stop codon) was amplified from pLUM305 (containing the complete $g l p K$ gene; the vector part is pHP13) using PCR. The sequences for the EcoRI and the $B a m H I$ restriction sites were introduced into the primers. The oligonucleotides used for PCR were $5^{\prime}$ TGTTTATAC GAATTCACATTCTGC $3^{\prime}$ (the EcoRI site is underlined) and $5^{\prime}$ CCAGGATCCCACAGCGATACCC $3^{\prime}$ (the BamHI site is underlined). The amplified fragment was purified using the Geneclean kit (Bio101). The fragment and p'TrcZZ were cut with EcoRI and BamHI and ligated. E. coli MM294 was transformed with the ligate and transformants were selected on TBAB plates containing Ap. A plasmid carrying the amplified $g l p K$ fragment was isolated from one transformant and designated pLUM630. The identity of the plasmid was verified by restriction cleavage and DNA sequencing. $E$. coli MM294(pLUM630) was grown in $250 \mathrm{ml}$ Luria broth containing Ap. Expression of the fusion protein was induced by addition of IPTG (final concentration $0.5 \mathrm{mM}$ ). After incubation for another $2.5 \mathrm{~h}$, the cells were harvested, washed with $0.9 \%$ $\mathrm{NaCl}$ and suspended in $2 \mathrm{ml} 10 \mathrm{mM}$ Tris/ $\mathrm{HCl}, \mathrm{pH} 8.0$. After sonication and centrifugation $(25000 \mathrm{~g}, 15 \mathrm{~min})$, the supernatant was diluted to $40 \mathrm{ml}$ and applied to an IgG Sepharose 6 Fast Flow column (Pharmacia). The column was first washed with 50 bed volumes of TST buffer $(50 \mathrm{mM}$ Tris/ $\mathrm{HCl}, \mathrm{pH} 7 \cdot 6$, $150 \mathrm{mM} \mathrm{NaCl}, 0.05 \%$ Tween 20 ), then with 20 bed volumes of $10 \mathrm{mM}$ ammonium acetate, $\mathrm{pH} 4 \cdot 6$. The bound protein was eluted with 5 bed volumes of $200 \mathrm{mM}$ acetic acid, pH 3.2, lyophilized and suspended in $50 \mathrm{mM}$ sodium phosphate buffer, $\mathrm{pH} 7 \cdot 0$. A rabbit was injected subcutaneously with $50 \mu \mathrm{g}$ fusion protein in Freund's complete adjuvant. Two booster injections using $2 \times 50 \mu \mathrm{g}$ fusion protein in Freund's incomplete adjuvant were given over a period of 6 weeks. Antiserum was collected and used without further purification.

Western blot. Glycerol kinase protein in cell extracts was detected by antibodies against glycerol kinase. The proteins 
were separated on an SDS polyacrylamide gel $(10 \%, w / v)$. Western blot analysis was done using a Western Exposure Chemiluminiscent Detection system (Clontech).

\section{RESULTS}

\section{Localization of suppressor mutations that allow a ptsGHI mutant to grow on glycerol}

Beijer \& Rutberg (1992) isolated independent revertants of a pts deletion mutant, LUG9001, that can grow on glycerol as sole carbon and energy source. In transformation crosses they showed that the corresponding mutations are linked to the glpPFKD region. To get the approximate location of the suppressor mutations, we cloned different parts of this region from the revertants using PCR. The PCR fragments were ligated to plasmid pHP13 and the resulting recombinant plasmids were introduced into LUG9001. $\mathrm{Cm}^{\mathbf{R}}$ transformants were selected and checked for growth on glycerol. From all five revertants, we derived a $1.4 \mathrm{~kb}$ fragment covering most of glpK (starting $63 \mathrm{bp}$ upstream of the start codon and ending $133 \mathrm{bp}$ upstream of the stop codon) that enabled LUG9001 to grow on glycerol. The corresponding fragment from the wild-type strain BR95 did not rescue LUG9001.

\section{The suppressor mutations are point mutations in glpK}

To map the above mutations precisely, $g l p K$ was cloned from the revertants and LUG9001. This was done by integrating plasmid $\mathrm{pHV} 32$ carrying the $g l p D$ control region which is located immediately downstream of $g l p K$ (see Fig. 1), into the chromosome of each strain. Plasmids containing $g l p K$ and part of $g l p F$ were regenerated in $E$. coli after cleavage of the chromosomal DNA with NcoI and ligation (Niaudet et al., 1982). From these plasmids, the DNA sequence of the entire $g l p K$ with flanking DNA (about 40 bp upstream of the start codon and about $70 \mathrm{bp}$ downstream of the stop codon) was determined. The five revertants were all found to have point mutations within the $5^{\prime}$-proximal half of $g l p K$. The mutations all lead to amino acid substitutions in glycerol kinase (Table 2). Two of the revertants, LUR9403 and LUR9404, had the same nucleotide change, a $\mathrm{T}$ to $\mathrm{C}$ transition at position 1101 . Two other revertants, LUR9401 and LUR9405, had nucleotide changes close to each other: LUR9401 had an A to $G$ transition at position 1386; and LUR9405 had a T to $C$ transition at position 1392 . The suppressor mutation

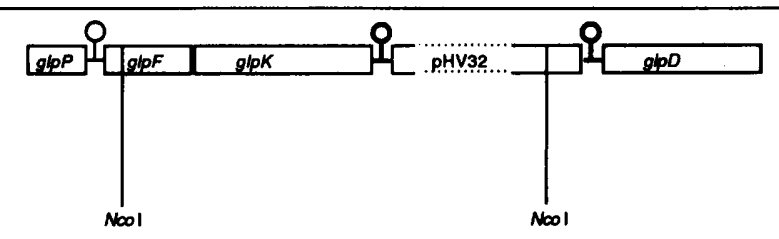

Fig. 1. Schematic representation of the gIPPFKD region with pHV32 integrated between $g / p K$ and $g / p D$. Inverted repeats are shown as stem-loops and the glpD control region, which is duplicated upon integration, is indicated by bold lines. The restriction sites for Ncol, which were used in regeneration of pHV32 containing glpK, are indicated.
Table 2. Nucleotide exchanges in glpK of the revertants and the corresponding amino acid substitutions in glycerol kinase

The positions of the nucleotide exchanges refer to the reported DNA sequence (GenBank accession number M34393).

\begin{tabular}{|ccc|}
\hline Strain & $\begin{array}{c}\text { Nucleotide exchange, } \\
\text { position }\end{array}$ & $\begin{array}{c}\text { Amino acid exchange, } \\
\text { position }\end{array}$ \\
\hline LUR9401 & A to G, 1386 & His to Arg, 230 \\
LUR9402 & A to G, 898 & Glu to Gly, 65 \\
LUR9403 & T to C, 1101 & Phe to Ser, 135 \\
LUR9404 & T to C, 1101 & Phe to Ser, 135 \\
LUR9405 & T to C, 1392 & Phe to Ser, 232 \\
\hline
\end{tabular}

of the fifth revertant, LUR9402, was an A to G transition at position 898. The DNA sequence of $g l p K$ from LUG9001 corresponds to the previously reported wildtype sequence (Holmberg et al., 1990, GenBank accession number M34393) except for a $C$ nucleotide at position 1298 which should be a G.

\section{Enzyme activities in the pts mutant, the revertants and the pts mutant carrying pLUM308}

Activities of glycerol kinase and G3P dehydrogenase were measured in extracts from the various strains grown with and without glycerol and G3P, respectively. The results are presented in Table 3. BR95, the wild-type, contained low, basal levels of the two enzymes when grown in minimal medium without glycerol and G3P. Addition of either substance induced both enzymes. Glycerol kinase activity increased two- to fivefold and G3P dehydrogenase activity five- to tenfold. The true inducer is G3P which means that a basal activity of glycerol kinase is necessary for G3P to be formed from glycerol. This can be seen in LUG9001. This strain cannot grow on glycerol and addition of glycerol induced neither glycerol kinase nor G3P dehydrogenase. However, addition of G3P induced both enzymes. The inability of LUG9001 to grow on glycerol must relate to an effect on the glycerol facilitator and/or the glycerol kinase which renders the cells unable to form the inducer, G3P. In all revertants, addition of glycerol as well as G3P induced glycerol kinase and G3P dehydrogenase activities. This demonstrates that the glycerol kinase of the revertants can form inducing amounts of G3P from glycerol, independently of the PTS.

Serendipitously, we have found that increasing the copy number of the $g l p F K$ operon also restores growth of LUG9001 on glycerol. Plasmid pLUM308 is pHP13 carrying $g l p F K$, a defective $g l p P$ and a truncated $g l p D$. When LUG9001 was transformed with pLUM308 it gained the ability to grow on glycerol. pHP13 containing only the $g l p P$ or the $g l p D$ operon, respectively, did not enable LUG9001 to grow on glycerol. LUG9001 carrying pLUM308 showed a somewhat lower glycerol kinase activity than BR95. It produced highly increased amounts of glycerol kinase protein compared to the wild type (or 
Table 3. Enzyme activities in the wild type, the pts mutant, the revertants and the pts mutant carrying pLUM308

The values represent the mean of at least two different measurements. The deviation from the mean is less than $30 \%$. Activities are expressed as nmol substrate converted $\mathrm{min}^{-1}$ (mg protein $)^{-1}$.

\begin{tabular}{|llcc|}
\hline Strain & Addition & $\begin{array}{c}\text { Glycerol } \\
\text { kinase }\end{array}$ & $\begin{array}{c}\text { G3P } \\
\text { dehydro- } \\
\text { genase }\end{array}$ \\
\hline BR95 & - & 7 & 3 \\
& G3P & 35 & 32 \\
LUG9001 & Glycerol & 17 & 62 \\
& - & 6 & 7 \\
& G3P & 18 & 31 \\
LUR9401 & Glycerol & 6 & 8 \\
& - & 1 & 2 \\
LUR9402 & G3P & 11 & 32 \\
& Glycerol & 6 & 60 \\
LUR9403 & - & 5 & 4 \\
& G3P & 27 & 24 \\
& Glycerol & 27 & 52 \\
LUR9404 & - & 4 & 5 \\
& G3P & 14 & 33 \\
& Glycerol & 24 & 78 \\
LUR9405 & - & 7 & 5 \\
& G3P & 33 & 29 \\
& Glycerol & 10 & 44 \\
& - & 1 & 4 \\
LUG9001(pLUM308) & G3P & 8 & 37 \\
& Glycerol & 34 & 14 \\
& G3P & 4 & 2 \\
& Glycerol & 10 & 8 \\
& & 20 & 5 \\
\hline
\end{tabular}

the revertants, data not shown), as determined by Western blots using antibodies against glycerol kinase (Fig. 2). It thus appears that the need for PTS in glycerol utilization can be overcome by an increased intracellular amount of glycerol kinase protein, possibly in combination with an increased amount of the glycerol uptake facilitator. The fact that the glycerol kinase activity was not increased shows that the need for a PTS-mediated activation is not overcome and the mutant can grow on glycerol only because glycerol kinase (and the glycerol facilitator) is overexpressed. The reason for the low G3P dehydrogenase activity may be that GlpP is titrated in the presence of the target region in multiple copies, giving a low expression of the intact chromosomal $g l p D$ operon.

\section{DISCUSSION}

The PTS affects glycerol utilization in both B. subtilis and $E$. coli. The activity of the $E$. coli glycerol kinase is controlled by one of the PTS components, EIIA ${ }^{\text {Glc }}$. This soluble enzyme, which is involved in transport of glucose, has a central regulatory function. It exists in a phosphorylated and an unphosphorylated form. When glucose is present, EIIA ${ }^{\text {Glc }}$ is predominantly in its unphosphorylated form since the phosphate group is transferred to glucose. The unphosphorylated EIIA ${ }^{\text {Glc }}$ has been shown to bind to and thereby inhibit the activity of proteins and enzymes involved in uptake/utilization of non-PTS sugars. One of these enzymes is glycerol kinase (Novotny et al., 1985). This inhibition of glycerol kinase activity in the presence of glucose will minimize unnecessary expression of the $g l p$ regulon since formation of inducer, G3P, is prevented.

B. subtilis does not have a soluble EIIA ${ }^{\text {Gle }}$. Instead, EIIA $^{\text {Glc }}$ is a domain in a membrane-bound polypeptide, EIICBA ${ }^{\text {Gle }}$. A control mechanism similar to the one found in E. coli is therefore unlikely. A B. subtilis ptsGHI mutant defective in the genes encoding EII ${ }^{\mathrm{Glc}}, \mathrm{HPr}$ and EI cannot grow on glycerol (Gonzy-Tréboul et al., 1991). This suggests a positively acting regulatory mechanism in which one or more of the central PTS components is needed for growth on glycerol. Beijer \& Rutberg (1992) showed that the ptsGHI mutant can grow on G3P and that its $g l p$ genes are induced by G3P but not by glycerol. This shows that one or more PTS components is needed for the utilization of glycerol but not of G3P and that the PTS-mediated control is separate from the specific control of the $g l p$ regulon. It was concluded that the glycerol uptake facilitator or the glycerol kinase are the most probable targets for PTS-mediated control. This control may involve phosphorylation of the proteins (see below).

Revertants of the pts mutant LUG9001 that can grow on glycerol as sole carbon and energy source, carry suppressor mutations that are linked to the $g l p$ region at $75^{\circ}$ (Beijer \& Rutberg, 1992). We have now characterized five such mutations. They are all translation missense mutations within the 5 -proximal half of the glycerol kinase gene (Table 2). In addition, we have found that increasing the amount of glycerol kinase protein (and the glycerol uptake facilitator) by increasing the number of gene copies also suppresses the glycerol-negative phenotype of LUG9001.

The crystal structure of the E. coli glycerol kinase in different complexes with glycerol, EIIA Glc of the PTS and ADP has been determined (Hurley et al., 1993). The glycerol kinases of $B$. subtilis and $E$. coli show high sequence identity $(62 \%)$. They are also equal in size; the B. subtilis enzyme consists of 501 amino acids (Holmberg et al., 1990) and the E. coli enzyme consists of 496 amino acids (Pettigrew et al., 1988). Furthermore, amino acid residues important for binding of glycerol in the $E$. coli enzyme are all conserved in $B$. subtilis. When discussing our results we will make the reasonable assumption that the glycerol kinases from these two bacteria are structurally similar.

In E. coli, catalytically active glycerol kinase exists in vitro (and probably also in vivo) as a mixture of dimers and tetramers. The proportion of tetramers increases at increasing concentrations of the enzyme. The latter form is also the form that is sensitive to allosteric control by fructose 1,6-diphosphate (de Riel \& Paulus, 1978). 


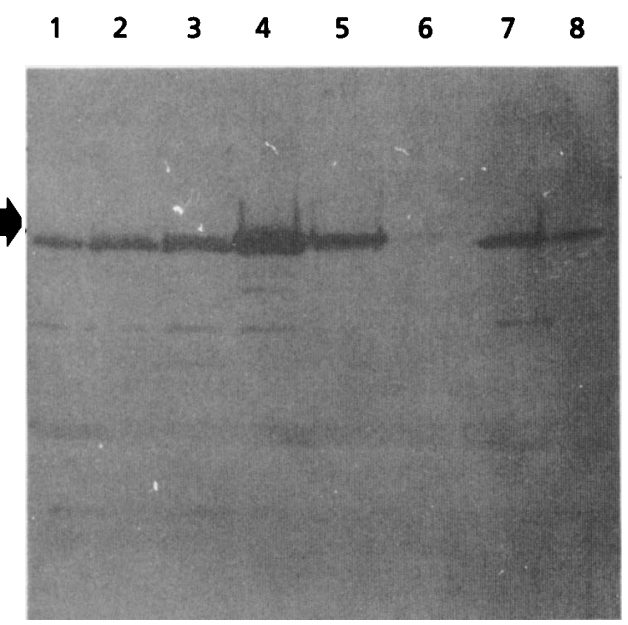

Fig. 2. Western blot analysis of glycerol kinase protein in cell extracts from BR95, LUG9001(pLUM308) and LUG0401, uninduced and induced with glycerol. LUG0401 is deleted for $g / p K$. Total protein $(12 \mu \mathrm{g})$ was loaded on lanes $1-4$ and 7-8. Lanes: 1, uninduced BR95; 2 , induced BR95; 3 , uninduced LUG9001(pLUM308); 4, induced LUG9001(pLUM308); 5, induced LUG9001(pLUM308) diluted 1:10; 6, induced LUG9001(pLUM308) diluted 1:50; 7, uninduced LUG0401; 8, induced LUG0401. The position of glycerol kinase (top band in double band) is indicated.

Voegele et al. (1993) have shown that in vivo, the E. coli glycerol kinase needs to associate with the glycerol uptake facilitator to be fully active.

In B. subtilis, components of the PTS exert positive control of glycerol utilization. A main function for PTS proteins is the transfer of phosphate groups, e.g. to drive the transport of various sugars into the cell or to control the expression of genes in carbohydrate catabolism, as in the E. coli bgl system (Amster-Choder \& Wright, 1993). In the Gram-positive Enterococcus faecalis, glycerol utilization is positively controlled by the PTS and it has been shown that glycerol kinase is activated by phosphorylation by the HPr (Deutscher \& Sauerwald, 1986; Romano et al., 1990). $\mathrm{HPr}$ of $B$. subtilis is phosphorylated at two different sites, at histidyl residue 15 by EI and at seryl residue 46 by an ATP-dependent $\mathrm{HPr}$ kinase. A recent report from Deutscher et al. (1994) suggests that phosphorylation at Ser-46 is not important for glycerol kinase activity.

We speculate that the PTS activates $B$. subtilis glycerol kinase in a manner that favours tetramerization of the enzyme and/or increases its affinity for the glycerol uptake facilitator. Possibly, this is achieved by phosphorylation of the kinase by P-his-HPr. The turnover of glycerol would then increase as a consequence of a more active glycerol kinase. Alternatively, an association of the glycerol kinase with the glycerol uptake facilitator would increase the concentration of glycerol near the kinase as glycerol enters the cell through the facilitator. Applying these speculations to the revertants of LUG9001 leads to the following interpretation of our results. The Phe to Ser substitution at position 135 in LUR9403 and LUR9404 is near the glycerol binding site in the similar $E$. coli enzyme (Fig. 3). The introduction of a more polar amino acid in
LUR9401, 9405

LUR9402

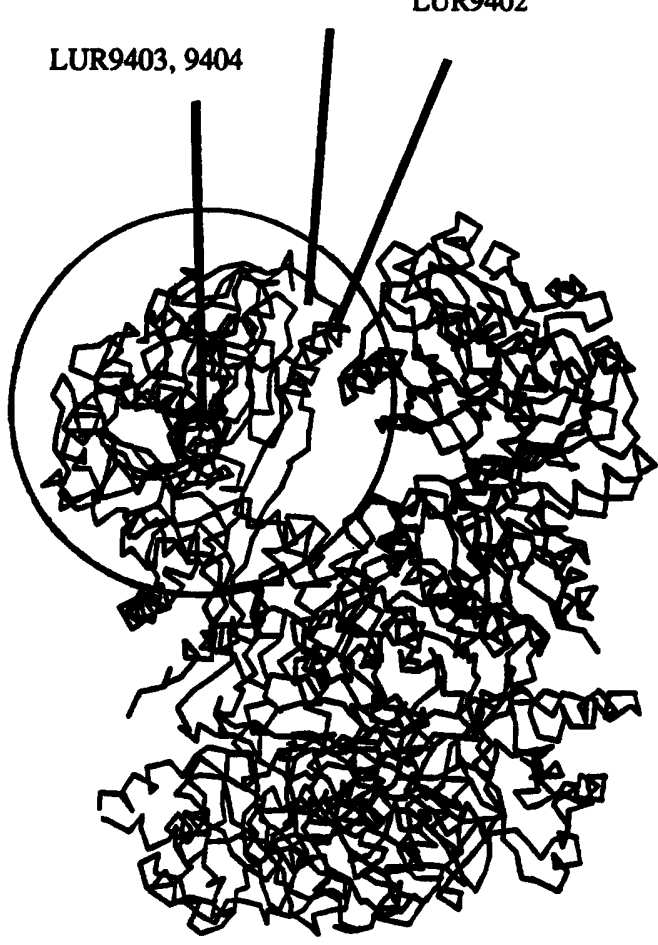

Fig. 3. A C $\alpha$ trace of the 3-dimensional structure of $E$. coli glycerol kinase in complex with glycerol. Within the encircled domain, the bound glycerol is indicated with a small circle. The amino acid residues predicted to correspond to those exchanged in the $B$. subtilis revertants are indicated. The protein structure was imported from the Brookhaven Protein Databank (Bernstein et al., 1977).

this region could increase the affinity of the enzyme for its substrate and bypass the requirement for increased tetramer formation or association to the facilitator. The other three amino acid changes (Glu to Gly at position 65, His to Arg at position 230 and Phe to Ser at position 232) are all located at the surface, in a part of the enzyme monomer which may be involved in protein-protein interactions (in the E. coli glycerol kinase, this part is involved in dimer-dimer contacts). We propose that these mutations promote formation of tetramers or increase the affinity of the kinase for the facilitator or make glycerol kinase activity independent of interaction with the facilitator. The changed glycerol kinase would then trap sufficient amounts of glycerol (by forming G3P) to allow growth.

Introduction of pLUM308 into LUG9001 leads to suppression of the glycerol-negative phenotype and a highly increased amount of glycerol kinase protein. The glycerol kinase activity is, however, quite low which could reflect the lack of PTS-mediated activation. It is not clear why a moderate increase in $g l p K$ (and $g l p F$ ) gene dosage results in such a large amount of glycerol kinase protein, but we propose that this high concentration of kinase protein allows some tetramerization and/or association with the glycerol facilitator in the absence of activation by the PTS. 
The above speculations lead to several testable predictions concerning regulation of glycerol catabolism in B. subtilis and its relation to the PTS. Our data establish that glycerol kinase is the major target for PTS-mediated control.

\section{ACKNOWLEDGEMENTS}

We are grateful to Ingrid Stål for excellent technical assistance and to Lars Rutberg for valuable advice and critical reading of the manuscript. We thank Salam Al-Karadaghi for help in interpreting the 3-dimensional structure of glycerol kinase. This project was supported by grants from the Swedish Medical Research Council, Emil and Wera Cornells Stiftelse and Crafoordska Stiftelsen.

\section{REFERENCES}

Amann, E., Brosius, J. \& Ptashne, M. (1983). Vectors bearing a hybrid $\operatorname{trp}$-lac promoter useful for regulated expression of cloned genes in Escherichia coli. Gene 25, 167-178.

Amster-Choder, O. \& Wright, A. (1993). Transcriptional regulation of the $b g l$ operon of Escherichia coli involves phosphotransferase system-mediated phosphorylation of a transcriptional antiterminator. J Cell Biochem 51, 83-90.

Anagnostopoulos, C. \& Spizizen, J. (1961). Requirements for transformation in Bacillus subtilis. J Bacteriol 81, 741-746.

Arwert, F. \& Venema, G. (1973). Transformation in Bacillus subtilis. Mol \& Gen Genet 123, 185-198.

Beijer, L. \& Rutberg, L. (1992). Utilisation of glycerol and glycerol3-phosphate is differently affected by the phosphotransferase system in Bacillus subtilis. FEMS Microbiol Lett 100, 217-220.

Beijer, L., Nilsson, R.-P., Holmberg, C. \& Rutberg, L. (1993). The $g l p P$ and $g l p F$ genes of the glycerol regulon in Bacillus subtilis. J Gen Microbiol 139, 349-359.

Bernstein, F. C., Koetzle, T. F., Williams, G. J. B., Meyer, E. F., Jr, Brice, M. D., Rodgers, J. R., Kennard, O., Shimanouchi, T. \& Tasumi, M. (1977). The protein data bank: a computer-based archival file for macromolecular structures. J Mol Biol 112, 535-542.

Deutscher, J. \& Sauerwald, H. (1986). Stimulation of dihydroxyacetone and glycerol kinase activity in Streptococcus faecalis by phosphoenolpyruvate-dependent phosphorylation catalysed by Enzyme I and HPr of the phosphotransferase system. J Bacteriol 166, 829-836.

Deutscher, J., Reizer, J., Fisher, C., Galinier, A., Saier, M. H., Jr \& Steinmetz, M. (1994). Loss of protein kinase-catalyzed phosphorylation of $\mathrm{HPr}$, a phosphocarrier protein of the phosphotransferase system, by mutation of the $p t s H$ gene confers catabolite repression resistance to several catabolic genes of Bacillus subtilis. J Bacteriol 176, 3336-3344.

Eisermann, R., Deutscher, J., Gonzy-Tréboul, G. \& Hengstenberg, W. (1988). Site-directed mutagenesis with the $p t s H$ gene of Bacillus subtilis: isolation and characterization of $\mathrm{HPr}$ proteins altered at the ATP-dependent regulatory phosphorylation site. J Biol Chem 263, 17050-17054.

Freedberg, W. B. \& Lin, E. C. C. (1973). Three kinds of control affecting the expression of the glp regulon in Escherichia coli. $J$ Bacteriol 115, 816-823.

Gay, P., Cordier, P., Marquet, M. \& Delobbe, A. (1973). Carbohydrate metabolism and transport in Bacillus subtilis. A study of ctr mutations. Mol \& Gen Genet 121, 355-368.

Gonzy-Tréboul, G., de Waard, J. H., Zagorec, M. \& Postma, P. W. (1991). The glucose permease of the phosphotransferase system of
Bacillus subtilis: evidence for $\mathrm{II}^{\mathrm{Gle}}$ and III ${ }^{\mathrm{Gle}}$ domains. Mol Microbiol 5, 1241-1249.

Haima, P., Bron, S. \& Venema, G. (1987). The effect of restriction on shotgun cloning in Bacillus subtilis Marburg. Mol \& Gen Genet 209, 335-342.

Holmberg, C. \& Rutberg, B. (1991). Expression of the gene encoding glycerol-3-phosphate dehydrogenase $(g l p D)$ in Bacillus subtilis is controlled by antitermination. Mol Microbiol 5, 2891-2900.

Holmberg, C. \& Rutberg, L. (1992). An inverted repeat preceding the Bacillus subtilis $g l p D$ gene is a conditional terminator of transcription. Mol Microbiol 6, 2931-2938.

Holmberg, C., Beijer, L., Rutberg, B. \& Rutberg, L. (1990). Glycerol catabolism in Bacillus subtilis: nucleotide sequence of the genes encoding glycerol kinase $(g l p K)$ and glycerol-3-phosphate dehydrogenase $(g l p D)$. J Gen Microbiol 136, 2367-2375.

Hurley, J. H., Faber, H. R., Worthylake, D., Meadow, N. D., Roseman, S., Pettigrew, D. W. \& Remington, S. J. (1993). Structure of the regulatory complex of Escherichia coli III $^{\text {Gle }}$ with glycerol kinase. Science 259, 673-677.

Lin, E. C. C., Koch, J. P., Chused, T. M. \& Jorgensen, S. E. (1962). Utilization of $\mathrm{L}$ - $\alpha$-glycerophosphate by Eschericbia coli without hydrolysis. Proc Natl Acad Sci USA 48, 2145-2150.

Lindgren, V. (1978). Mapping of a genetic locus that affects glycerol-3-phosphate transport in Bacillus subtilis. J Bacteriol 133, 667-670.

Lindgren, V. \& Rutberg, L. (1974). Glycerol metabolism in Bacillus subtilis: gene-enzyme relationships. J Bacteriol 119, 431-442.

Mandel, M. \& Higa, A. (1970). Calcium-dependent bacteriophage DNA infection. $J$ Mol Biol 53, 159-162.

Marmur, J. (1961). A procedure for the isolation of deoxyribonucleic acid from microorganisms. $J$ Mol Biol 3, 208-218.

Niaudet, B., Goze, A. \& Ehrlich, S. D. (1982). Insertional mutagenesis in Bacillus subtilis: mechanism and use in gene cloning. Gene 19, 277-284.

Nilsson, R.-P., Beijer, L. \& Rutberg, B. (1994). The $g l p T$ and $g l p Q$ genes of the glycerol regulon in Bacillus subtilis. Microbiology 140, 723-730.

Novotny, M. J., Frederickson, W. L., Waygood, E. B. \& Saier, M. H., Jr (1985). Allosteric regulation of glycerol kinase by Enzyme $\mathrm{III}^{\mathrm{Glc}}$ of the phosphotransferase system in Eschericbia coli and Salmonella typhimurium. J Bacteriol 162, 810-816.

Pettigrew, D. W., Ma, D.-P., Conrad, C. A. \& Johnson, J. R. (1988). Escherichia coli glycerol kinase. J Biol Chem 263, 135-139.

de Riel, J. K. \& Paulus, H. (1978). Subunit dissociation in the allosteric regulation of glycerol kinase from Escherichia coli. 1. Kinetic evidence. Biochemistry 17, 5134-5140.

Romano, A. H., Saier, M. H., Jr, Harriott, O. T. \& Reizer, J. (1990). Physiological studies on regulation of glycerol utilization by the phosphoenolpyruvate:sugar phosphotransferase system in Enterococcus faecalis. J Bacteriol 172, 6741-6748.

Sanger, F., Nicklen, S. \& Coulson, A. R. (1977). DNA sequencing with chain-terminating inhibitors. Proc Natl Acad Sci USA 74, 5463-5467.

Voegele, R. T., Sweet, G. D. \& Boos, W. (1993). Glycerol kinase of Escherichia coli is activated by interaction with the glycerol uptake facilitator. J Bacteriol 175, 1087-1094.

Received 28 October 1994; revised 3 January 1995; accepted 19 January 1995. 